\title{
Ischaemic stroke of the fornix and genu of the corpus callosum presenting with a Korsakoff-like syndrome
}

\author{
Jeremy Boardman, ${ }^{\circledR}$ Adam Zermansky
}

Neurology Department, Greater Manchester Neuroscience Centre, Salford Royal NHS Foundation Trust, Salford, UK

\section{Correspondence to} Dr Jeremy Boardman, jeremy.boardman@srft.nhs.uk, j.boardman@doctors.org.uk

Accepted 12 March 2019

\section{DESCRIPTION}

An 80-year-old man was admitted with 'acute confusion'. Previously he was completely independent (modified Rankin score of 0 ). The day before the presentation, he was performing complex accounting work for his family business. He had a medical history of hypertension and diabetes mellitus. His alcohol intake was $<20$ Units a week and there was no history of malnutrition.

The presentation was triggered by a sudden change in behaviour noted by his granddaughter.

Examination revealed marked anterograde memory loss with prominent confabulation. On questioning, he explained he was in a hospital to visit a friend who had just left the room. His retrograde memory was intact with the correct recollection of all his family members and he was able to give an accurate account of his previous work and business. Aside from hallucinating at night, other cognitive domains were spared and he scored 23/30 on the Montreal Cognitive Assessment, with deficits in delayed recall and orientation in time. Further neurological examination was unremarkable.

Investigations included normal serum inflammatory markers, B12 and folate. EEG was normal with no evidence of encephalopathy. Cerebrospinal fluid (CSF) constituents showed a mildly raised white cell count of $9 \times 10^{6} / \mathrm{L}$ and protein $0.57 \mathrm{~g} / \mathrm{L}$. Initially, he was treated with aciclovir in case of herpes simplex virus (HSV) encephalitis, which was stopped as the CSF viral PCR result was negative.

MRI scan 5 days after onset of symptoms showed a lesion in the anterior corpus callosum and bilateral columns of the fornix with high signal on diffusion-weighted imaging and low signal on the apparent diffusion coefficient (ADC)

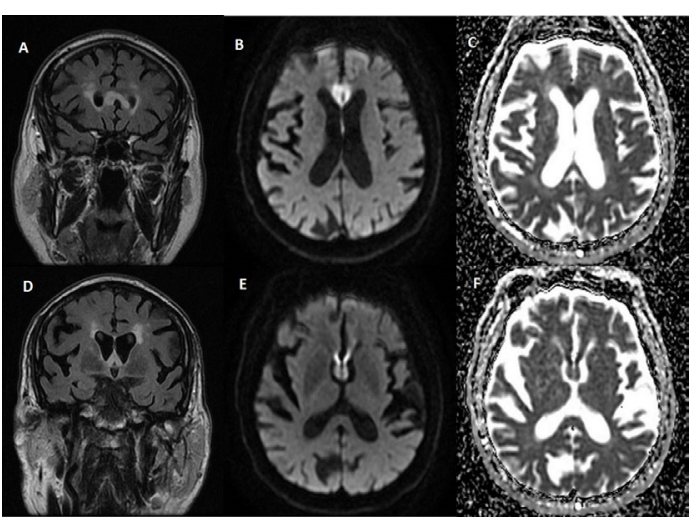

Figure 1 Initial MRI brain.

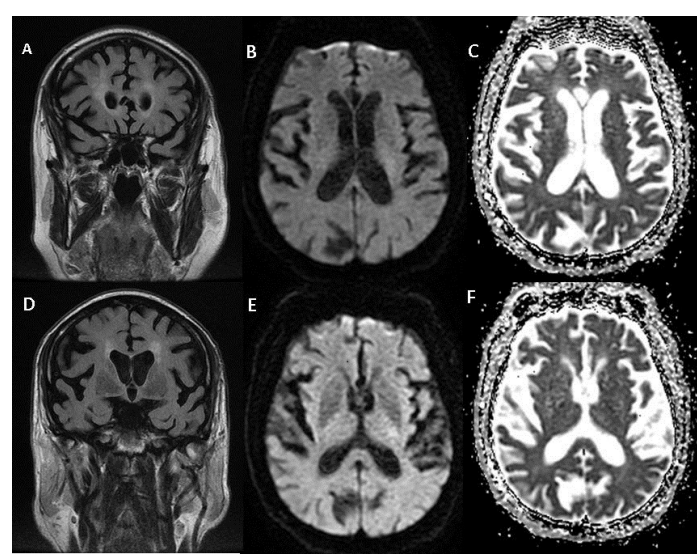

Figure 2 Repeat MRI brain.

map, consistent with acute infarction (figure 1). There was evidence of microvascular disease and an old left cerebellar infarct. Follow-up scan after 4 months showed resolution of the restricted diffusion and expected maturation of the lesions (figure 2).

The fornix is a white matter tract operating as an output of the hypothalamus, connecting it with the medial temporal lobes. As part of the Papez circuit, it plays an important role in the formation and consolidation of new memories. ${ }^{1}$

The bilateral columns of the fornix and the genu of the corpus callosum are typically supplied by the subcallosal artery, which is the largest of the three major perforating branches arising from the anterior communicating artery (AcoA).

While this man's initial presentation was labelled as confusion, further evaluation revealed specific deficits of memory expressed as anterograde amnesia and confabulation, otherwise global cognitive function was preserved.

Though previously described, ${ }^{2}$ acute amnestic syndrome due to infarction of the fornix is a rarity, most commonly reported as a complication of endovascular treatment of AcoA aneuryms. ${ }^{3}$ While this presentation may lead the clinician to consider aetiologies such as thiamine deficiency, Marchiafava-Bignami disease and even HSV encephalitis, the

\section{Learning points}

- Ischaemic stroke should be considered as a differential in sudden onset amnestic syndromes.

- Localising cognitive deficits is important in enabling accurate diagnosis. 
tempo of onset, in this case, was more suggestive of a vascular cause.

This case highlights the importance of defining and localising cognitive deficits, rather than using the vague term 'confusion'. Clinicians should be aware of stroke as a cause of a Korsakoff-like syndrome, particularly following the acute presentation.

Contributors JB: conception of manuscript, design and acquiring of information; drafted and revised the manuscript. AZ: supervised production of the manuscript; involved in manuscript design, interpretation of data and revision of initial draft. Both authors approved the final version and agreed to be accountable for all aspects of the work.
Funding The authors have not declared a specific grant for this research from any funding agency in the public, commercial or not-for-profit sectors.

Competing interests None declared.

Patient consent for publication Obtained.

Provenance and peer review Not commissioned; externally peer reviewed.

\section{REFERENCES}

1 Papez JW. A proposed mechanism of emotion. 1937. J Neuropsychiatry Clin Neurosci 1995;7:725-33.

2 Salvalaggio A, Cagnin A, Nardetto L, et al. Acute amnestic syndrome in isolated bilateral fornix stroke. Eur J Neurol 2018:25:787-9.

3 Mugikura S, Kikuchi H, Fujii T, et al. MR imaging of subcallosal artery infarct causing amnesia after surgery for anterior communicating artery aneurysm. AJNR Am J Neuroradiol 2014;35:2293-301.

Copyright 2019 BMJ Publishing Group. All rights reserved. For permission to reuse any of this content visit https://www.bmj.com/company/products-services/rights-and-licensing/permissions/

BMJ Case Report Fellows may re-use this article for personal use and teaching without any further permission.

Become a Fellow of BMJ Case Reports today and you can:

- Submit as many cases as you like

Enjoy fast sympathetic peer review and rapid publication of accepted articles

- Access all the published articles

Re-use any of the published material for personal use and teaching without further permission

For information on Institutional Fellowships contact consortiasales@bmjgroup.com

Visit casereports.bmj.com for more articles like this and to become a Fellow 